\title{
Mahatma Gandhi National Rural Employment Guarantee Act (MGNREGA) as Social Safety Net: Analysis of Public Works in Odisha, India
}

\section{Tushar Kanti Das ${ }^{1}$}

\begin{abstract}
Social safety nets are transfers targeted to the poor or vulnerable. They facilitate access to health and education services to build human capital. To achieve the Sustainable Development Goals (earlier known as Millennium Development Goals), national and state governments as well as international organisations have focused on increasing the investments in social transfer programmes. Public works are the policy instruments for mitigating the negative effects of climatic and systematic risks on poor farmers and unskilled and semi-skilled workers. The Mahatma Gandhi National Rural Employment Guarantee Act (MGNREGA) is the largest social protection programme in the world that provides 100 days of unskilled wage employment to any household residing in rural areas whose adult members volunteer to do unskilled manual work. In the state of Odisha the MGNREGA scheme is widely implemented. However, the irregularities involved in the implementation of this social protection programme are of great concern. The present study focuses on the implementation of MGNREGA in three districts of western Odisha. The study has tried to identify the bottleneck in the success of MGNREGA scheme.
\end{abstract}

Key words: MGNREGA Scheme, Public Works, Social Safety Net, Workfare

JEL Classification: D02, J38, H55, I38

Received: 10 July 2015 / Accepted: 23 September 2016/Sent for Publication: 9 December 2016

\section{Introduction}

Public work provides the means to tackle poverty, empowers minorities by being more inclusive. The world of work is changing more rapidly than ever before. Decent work has provided people with a sense of dignity and opportunity to engage fully in the society. The quality of work is an important dimension of ensuring that work enhances human development (UNDP, 2015). Putting job creation at the heart of economic policy-making, the development plans will generate decent work opportunities. It will also lead to inclusive and poverty-reducing growth. It is a virtuous circle that is good for

\footnotetext{
1 Associate Professor, P.G. Department of Business Administration, Sambalpur University, Jyoti Vihar, Sambalpur-768019, Odisha, India, Email: tkdas@live.com, tkdas@suniv.ac.in

C 2016 by the authors; licensee Review of Economic Perspectives / Národohospodářský obzor, Masaryk University, Faculty of Economics and Administration, Brno, Czech Republic. This article is an open access article distributed under the terms and conditions of the Creative Commons Attribution 3.0 license, Attribution - Non Commercial - No Derivatives.
} 
the economy as well as the people and it drives sustainable development ${ }^{2}$. Safety nets are only part of the broader strategy of poverty reduction. They interact with and work alongside the social insurance such as health, education and financial services; the provision of infrastructures like roads and various other policies which aim at reducing poverty and managing risks. Safety nets aim to redistribute income to the poorest with an immediate impact on the poverty and inequality reduction (Grosh et al 2008). They are transfers targeted to the poor.

Social safety nets are transfers targeted to the poor or vulnerable in some manner. They are: a) cash transfers - unconditional or conditional; narrowly targeted to the poor or covering all people who belong to the vulnerable categories in the population such as children, elders and disabled; b) transfers in kind - most commonly school feeding, food rations and other essential goods delivered in kind; c) income support delivered in exchange for participation in work or training activities; and d) fee waivers in essential services such as health or education. Social safety nets are only part of wider social protection, poverty reduction and development strategies. A social protection policy will include social insurance - including unemployment insurance - labour and training programs and labour regulation. A full social policy will include education and health, housing, access to utilities, as well as social protection (Development Committee 2012).

Currently, 80 percent of developing countries have plans to strengthen their safety nets to better respond to future crises (IEG 2011). Need for social safety nets is a critical concern for governments across the world. Since 2008, dozens of countries have created new safety net programs. They have expanded old ones, improved administrative systems and governance arrangements to modernize their programs to make them more efficient. This explosion of policy action assists the clients and countries directly involved in the practice of safety nets. At the same time many men, women and children are struggling to improve their livelihood. As interests in the use of social safety net interventions keep increasing, countries strive to make social safety net interventions more effective. Therefore, countries try to integrate these interventions in their overall social protection and labour systems (World Bank, 2015).

Safety nets take different forms, encompassing comprehensive programs like Brazil's Bolsa Familia that assists poor families with cash payments, or Liberia's cash-for-work program providing access to public works jobs, or school feeding programs or academic stipends designed to address temporary nutrition and gender gaps. The safety nets program like Ethiopia's program and school feeding in Nicaragua save lives, i.e., providing families with a basic income, and keeping children healthy and in school during the food, fuel and financial crises. Where such programs are absent, people more often faced malnutrition and are forced to sell assets, cut back their expenditures on food and health care, and pull their children out of school.

In India the implementation of wage employment programs provide unskilled workers with short-term employment in public works. They provide income transfers to poor households especially during lean periods. The wage employment programs implemented by state governments with central assistance are self-targeting, and the

\footnotetext{
${ }^{2}$ The eighth goal of the new 2030 agenda for Sustainable Development Goals (SDG) calls for the promotion of sustained, inclusive and sustainable economic growth, full and productive employment and decent work (UNDP, 2016).
} 
objective is to provide enhanced livelihood security, particularly to those dependent on casual manual labour. In this regard MGNREGA is a powerful instrument for ensuring inclusive growth in rural India through its impact on social protection, livelihood security and democratic empowerment. The mandate is to provide at least 100 days of guaranteed wage employment in a financial year to every rural household whose adult members volunteer to do unskilled manual work. ${ }^{3}$

MGNREGA scheme completed a decade in February 2016. This has been a landmark public programme in many respects. It is the first right based public programme in India and the largest in the world in terms of potential demand. It is the first public programme that mandates community-led monitoring of local expenditures and reservation of one third of programme beneficiaries for women. It envisages a bottomup approach in public programme implementation. As a public works programme, one of the main intended benefits of MGNREGA is the creation of additional employment. The scheme also has the potential to affect rural labour markets when alternative job opportunities are available (Zimmermann 2013, 2014).

With the implementation of MGNREGA, it was envisaged that it would create 'durable assets'. Yet, across states, most of the early years were devoted to putting the basic prerequisites for programme implementation in place. The record of asset generation was far from inspiring. This prompted the World Bank to remark that the spillover benefits from assets created are unlikely to have made it felt just yet, see Narayanan (2016). MGNREGA, when it came into being, was seen as a transformative piece of legislation that would go a long way in addressing the chronic poverty that one witnesses in rural India. That it has not been achieved in the way that was envisaged by the advocates of MGNREGA may be due to a certain naivety in understanding the implementation challenges and some of the features of the Act that were seen to be desirable. However, MGNREGA has radically transformed the manner in which poor rural households view their rights as citizens, and has served as a critical source of livelihood for many of the poorest households at times when no work was available in private rural labour markets. MGNREGA has not been a complete success, but it has significant potential to transform power relations in the rural countryside - a potential that has not been realised even 10 years after the initiation of the programme, Sen (2016). A substantial empirical literature has looked at the effects of MGNREGA on a range of outcomes. MGNREGA has the potential to play a key role in providing economic security to individuals and households, rising awareness of entitlements, creating durable community assets and empowering women and improving child level outcomes.

The present study aims for analysing the development effectiveness of MGNREGA scheme in three districts of Western Odisha in India. That is the study is an explorative initiative towards the effective implementation of MGNREGA. Differences in the outcomes in terms of employment, wages and effect on migration are the specific objectives. The reason behind selecting districts from the western region is that this region is comparatively less developed from their coastal counterparts. The specific objectives are First: to examine from a comparative perspective implementation of

\footnotetext{
${ }^{3}$ For an excellent discussion on MGNREGA, see Afridi (2016).
} 
MGNREGA scheme in different villages of Odisha; Second: to analyse differences in outcomes in terms of employment, wages and effect on the livelihood of the people.

The present section introduces the problem under study. Motivation \& macroeconomic problem of public works is presented in section-2. Comparisons of different types of social security schemes are outlined in section-3. Multiplier effect of these schemes / programmes is also discussed in this section. In section-4 the MGNREGA (2005) scheme as adopted by Government of India is presented. Section-5 deals with data source and methodology. Selection criteria, district profile, sample size and sampling procedure are presented in this section. Findings and analysis of the study are presented in section-6. Issues relating to card holding and working conditions of beneficiaries under MGNREGA scheme are also presented in this section. The concluding remarks about the study are presented in section- 7 .

\section{Motivation}

Large scale unemployment is widespread in developing countries. Job opportunities are especially scarce during the agricultural off-season. The situation is worse in bad economic times and credit and insurance markets are not developed enough to help households cope with income fluctuations. In this context of market failures, public works programmes promise substantial benefits in reducing poverty. Governments can step in and directly provide employment opportunities in infrastructure and construction projects, increasing household income. This often provides a safety net in times of economic shock. These promised benefits have made public works programmes a popular policy tool in developing countries for several years but particularly in the last decade. Whereas many older programmes were temporary and tried to address shortterm unemployment, several newer initiatives have been large and have focused on creating longer lasting schemes that offer a safety net and predictable longer-term support for poor households. (Zimmermann, 2014).

Public works programmes have potential advantages and drawbacks as anti-poverty initiatives in developing countries, but the evidence on their effectiveness is weak. Public works programmes in developing countries can reduce poverty in the long run and help low skilled workers to cope with economic shocks in the short term. But success depends on a scheme's design and implementation. Key design factors are properly identifying target population, selecting the right wage and establishing efficient implementation institutions.

\section{Comparison of the Social Security Schemes}

Social welfare schemes all over the world are going through interesting times. Bound by fiscal management targets welfare cuts are routinely passed off as 'reforms'. Usually there is pressure on governments to target welfare to the most deserving (Chattopadhyay, 2015). Social scientists outline the political economy of targeting in universal social security schemes. These suggest inclusive social security schemes build potential alliances between those living in poverty, those on middle incomes and the 
affluent (Kidd, 2015). The Washington Consensus ${ }^{4}$ called for 'social safety nets' to be 'targeted at the poor'. Political economy of targeting theory holds true in a wide range of contexts. When compared to poverty target schemes, inclusive social security transfers receive more public funding, offer higher value transfers to the recipients and have much quality implementation, with fewer people living in poverty are excluded. They are also much more effective in their impacts on poverty and inequality. Different targeting mechanisms are associated with systematic differences in terms of inclusion and exclusion errors, financial costs and secondary consequences. An 'ideal' outcome would be to identify the most efficient and cost-effective targeting mechanisms to provide an unambiguous answer to the policy-makers' question (Devereux et al, 2015).

Public works have long been considered a staple of social assistance programs (Grosh et al. 2008). However, for the most part, they have been designed as short-term 'safety nets' (Subbarao et al. 2013; del Ninno et al. 2009). While, in some cases, the focus has been on poverty reduction or addressing structural unemployment challenges (e.g., those arising from shifts in labour intensity in growth sectors and/or decline in sectors that were relatively better at absorbing labour), they have seldom been implemented on a scale that would allow them to make a dent in structural poverty (Lal et al. 2010). Most developing countries that followed the dominant development theories to design development policies failed to achieve the goal of narrowing the income gap with developed countries (Lin et al. 2012).

Employment Guarantee Schemes (EGSs) and Cash Transfers (CTs) are social protection programs which are intended to have a positive impact on the poor, primarily in terms of increased household income. The former through the provision of wage on the basis of work requirement and the latter through the provision of cash transfer (Hagen-Zanker et al 2011, Prabhu, 2009). EGSs provide a guaranteed amount of employment each year, hence a guaranteed income, usually providing payment in the form of cash. Existing EGS programs have stricter workfare guidelines (Basu 2013). CTs provide a direct cash payment, to households or individuals, which may be unconditional (UCTs), or may have conditions attached such as a requirement for school or clinic attendance by children, in which case they are known as conditional cash transfer programs (CCTs). By providing households with additional income, both CCTs and UCTs make it easier for households to access health and educational services among others. The choice between a CCT and a UCT should be driven by what policy makers want to achieve and who they want to target with the program. EGSs are sometimes considered to be a particular form of conditional cash transfers, with the condition being the work requirement (Zepeda et al 2012; Zepeda et al 2013).

EGSs are a subset of Public Works Programs (PWPs), but should not be confused with this broader category of interventions, which typically provide only one type of and short term employment opportunities. EGSs guarantee employment to a specified population over a sustained or indefinite period. They differ from CTs in that receipt of

\footnotetext{
${ }^{4}$ The concept and name were first presented in 1990 by John Williamson, an economist from the Institute for International Economics, Washington DC. The Washington consensus contained a set of 10 recommendations that synthesized the policies considered necessary for the recovery of Latin American economies from the financial crisis of the 1980s and cycles of high inflation and low growth.
} 
a transfer is conditional on satisfying a work requirement, usually, but not exclusively, relating to manual labour. While EGSs are rare, CT programs are significantly more diverse in conception and execution, far more frequently implemented, and may or may not offer sustained or guaranteed transfers.

The differences in program design are likely to affect impacts, as is the fact that the two types of intervention may be targeted at different groups, with EGS participation limited to households with available labour (adequate numbers of members of working age), while CTs target households or individuals on the basis of a more diverse set of criteria, which are often demographic (including the presence of the elderly, orphans and vulnerable children or young children within households, or the absence of members of working age). For these reasons, general comparisons of social security schemes may not necessarily be meaningful (Barrientos et al 2008; Jorgensen et al. 2009).

For policy makers, it is important to assess the impacts of these social security schemes. EGSs and CTs are often seen as substitutes by policy makers, since only one or the other is accessible by a particular group of beneficiaries. In the few instances, they are treated as complements, and implemented in parallel for different population groups, as in the case of the Productive Safety Nets Program (PSNP) in Ethiopia, which has both CT and EGS components, with the CT component being available for households unable to participate in the EGS. As a consequence, it is not possible to make generalised comparisons between the impacts of the two different interventions as they are often implemented in different contexts and target populations (Hagen-Zanken et al 2011).

Safety Net program in Indonesia is expected to reach 6.5 million households in extreme poverty. Bolsa Familia in Brazil reaches a further 12 million households. Ethiopia's Productive Safety Net Program (PSNP) reaches 1.7 million households. In South Africa, social assistance grants reach one half of the households. In low-income countries, the growth has been slower, but noticeable. Social transfer programs have the potential to make a significant contribution to global poverty reduction. Transfer programs in developing countries show diversity in program design. Pure income transfers, like South Africa's Old Age Grant, supplement the purchasing power of households in poverty. In other countries, income transfers combined with access to basic services or improvements in infrastructure have been introduced. For example, Mexico's Oportunidades links transfers to school attendance and primary health care utilization with the objective of reducing intergenerational poverty persistence. Social transfers conditioned on labour supply link the transfer to local infrastructure development.

Transfers of these types could strengthen the productive capacity of households in poverty by setting out a basic framework with which to collect, organize and assess the relevant findings from existing evaluation studies. The impact of transfer programs on micro level growth among poor and poorest groups as it is unlikely that they could influence aggregate GDP growth. The basic framework mapped out the potential linkages existing between social transfers, growth mediating processes and outcomes relating to the productive capacity of households in poverty (Barrientos 2012). 


\subsection{Multiplier Effect}

The multiplier theory explains the cumulative effect of changes in investment on income via their effects on consumption expenditure. The multiplier measures the response of the economy to change in demand of a sector. When total output of a sector increases, it has both direct and indirect effect on the economy. Direct effects are the immediate effects associated with the change in final demand for a particular sector or industry. In addition to the direct effects, the indirect effects or the secondary effects are due to backward linkages of sectors. Public works create labour demand and if they are not useless public works, the income or value added multiplier gives an estimate of the direct and indirect employment changes resulting from a change in unit output.

In areas with high poverty incidence, household income growth can be constrained by community-level factors, such as the absence of adequate infrastructure or the scarcity of local liquidity and trade. Transfer programs conditional on labour supply could in principle have an impact on both these factors, by transferring income to households and improving liquidity, while at the same time upgrading available infrastructure. In practice, the assessment of such programs has been overall very mixed. Many public works programs transfer only a fraction of their budget to beneficiary households, due to the cost of inputs, equipment and technical advice; and in some cases, the value of newly created infrastructure is marginal. Studies assessing the impact of public works programs find that their impact at the community level depends to an important extent on program design, especially the level and periodicity of the transfer (McCord 2007).

Transfer programs can also improve liquidity and trade at the local economy level by stimulating effective demand. Only a handful of studies have addressed this question. In the context of direct income transfer programs, existing studies suggest social transfers could generate multiplier effects, especially in poor rural areas, but evidence on multiplier effects from social transfers must be considered with great care.

\section{MGNREGA (2006) Scheme}

The Government of India has taken an "inclusive growth" approach to poverty reduction, with one of the main flagship programs being MGNREGA - a public works program reaching up to 45 million households aimed at supporting a transformation in rural livelihoods and agricultural productivity in India through public works. The Act has two-fold objectives: First, it aims to provide gainful employment and reduce poverty, improving the purchasing power of the rural people, primarily semi-skilled or unskilled people living in rural India, and was primarily meant for people living below the poverty line. Second, it aims to create public assets in the rural areas such as roads, water tanks, and other common property resources that will help residents overcome other hardships associated with poverty.

There are two types of governance challenges that make the large-scale implementation of social safety nets in rural areas. They are (1) the challenge of avoiding elite capture and of actually reaching the poor and the disadvantaged and (2) the challenge of managing the funds allocated to the program effectively and avoiding leakages and corruption. MGNREGA is a rights-based approach (Raabe et al. 2010). In the words, as quoted in (UNDP 2009), MGNREGA exemplifies the features of a "mature democracy", which provides "the poor with the right to demand, the right to know and 
the right to dignity. Not the right to beg." The second challenge is more difficult to meet because MGNREGA involves two features that have been highlighted in the literature as particularly challenging. First, the program is "transaction-intensive" in terms of time and space: It requires day-to-day action throughout a country that spans an entire subcontinent. Second, the program requires discretion, since decision making on issues such as the type of infrastructure to be created under the program cannot easily be standardized.

Informed by India's far-ranging experience in managing rural welfare programs, MGNREGA has already gone a long way in including innovative design features aimed at overcoming the well-known implementation challenges of such programs. This scheme is implemented in a decentralized manner and includes substantial checks and balances as well as oversight and complaint mechanisms. Yet, available evidence indicates that massive implementation problems remain. Farmers have opposed the implementation of the scheme during peak season of agriculture precisely because of its effect on wages (Imbert et al. 2012). At the same time, there are constant efforts to adjust the implementation procedures to resolve these challenges.

The MGNREGA goes beyond poverty alleviation and recognizes employment as a legal right. In the past, it has posed no problem for the budget. Its allocation is marginally higher than what was spent in the past by the government on various rural employment programmes. It is a demand driven scheme and it has fallen far short of meeting demand in some states. The fund utilization also varies widely across states. Just as the MGNREGA provides opportunities for the rural households and to an extent a livelihood security, it presents formidable challenges in implementation (Chakraborty, 2007).

Issues around the implementation of MGNREGA with focus on its institutions, governance and innovations are analysed by Reddy, et al (2010). Based on field study in three Indian States, the study concludes that differential impacts and achievements of MGNREGA are related to variations in the commitment of local leadership, levels of institutional preparedness and governance capabilities. Although the households are reported reduced hunger they are silent about any reduction in migration. There is a strong and significant correlation between a state's literacy rate and its level of success in implementing MGNREGA (Bonner et al, 2012).

With regard to transparency, the MGNREGA worksites having muster rolls verified has a strong relationship with success. It remains unclear whether MGNREGA is primarily responsible for rising agricultural wages across India. Participation in MGNREGA is growing rapidly despite the appearance of stagnant growth (Johnson et al, 2009). It reaches different people than any other Government programme. MGNREGA has provisions that aim at improving the participation of women. These have met with varying degrees of success in different parts of the country. Serious problems remain in implementation across states. Given the critical gains made by women workers it needs to be ensured that the problems of implementation do not derail the gains (Khera \& Nayak 2009).

The first goal of the SDG is to eradicate extreme poverty and hunger. The target is to achieve full and productive employment and decent work for all, including women and young people. This is one of the most effective routes to eradicate poverty. Suitably 
designed employment guarantee programs can contribute to the SDGs in a variety of ways ranging from the provision of employment per se to addressing SDG-related infrastructure and service delivery deficits (Lal et al. 2010). The Mahatma Gandhi National Rural Employment Guarantee Act made supplementary livelihood in rural areas through unskilled manual work a legal right.

The centerpiece of the 11th Plan's battle against rural poverty was the MGNREGA. The MGNREGA has delivered the largest employment program in human history, which is unlike any other in its scale, architecture and thrust. Its bottom-up, people-centered, demand-driven, self-selecting, rights-based design is new and unprecedented. Never have in such a short period so many crores of poor people benefited from a government program (Planning Commission 2012).

\subsection{MGNREGA: 2.0}

As a part of the next level of implementation of MGNREGA, viz. MGNREGA 2.0, Government of India (GoI) has taken up some of the recent initiatives and reforms. The GoI released the revised MGNREGA operational guidelines based on the recommendations of the Mihir Shah Committee (Ministry of Rural Development 2012). The list of permissible works under MGNREGA has been expanded to: i) strengthen the positive synergy between MGNREGA and agriculture and allied rural livelihoods; ii) to respond to the demands of the States greater location specific flexibility in permissible works; and iii) to help improve the ecological balance in rural India.

Some of these works are new but many of them within category of works already permitted under MGNREGA. The list was drawn up in response to demands from States for a more elaborate, specific and unambiguous list of works that could be taken up under the categories currently permissible. While taking up the works under MGNREGA, the following conditions need to be followed. They are: First, only those works to be taken up that result in creation of durable assets; Second, the order of priority of works to be determined by the Gram Panchayat (GP); Third, 60:40 ratios for labour: material costs should be maintained at the GP Level; and Fourth, no contractors / labour - displacing machinery to be used.

The expert group has recommended adding 30 Agriculture and allied works under the rural job guarantee scheme with the objective of making the programme more effective. These include agriculture, animal husbandry, poultry, drinking water, sanitation and watershed-related works. Besides the committee also suggested for ensuring demand based character of MGNREGA; effective planning; strict time schedule; deployment of human resources; reducing delays in wage payments; strengthening MIS; equal opportunity for vulnerable groups; greater role for civil society organisations; and better social audits and vigilance for transparency and accountability (Ministry of Rural Development 2013).

MGNREA is meant for the entire rural adult population without any criteria for getting employment. As long as one is ready to do hard manual work one can demand and get work at the notified wage. Now there is a move that the programme be scaled back to just 200 backward districts. This will translate to fewer people / villages benefiting from the programme and to a reduction of fund requirement (Kulkarni, 2014). 


\subsection{Outcome of the MGNREGA Scheme}

The main proximate reason for the scheme's disappointing performance is that many people in rural India who want MGNREGA work have not been able to get the work. There is extensive rationing of the available jobs across India, especially in poorer states. Also, payment of the unemployment allowance appears to be a rarity. It does not mean that the scheme is 'poorly targeted'. Critics typically mean extensive leakage to the non-poor. Evidence suggests that the scheme is reaching relatively poor families, even allowing for the un-met demand for work (Dutta et al 2014).

The outcome of the MGNREGA programme in terms of Job card and the type of workers in both Odisha and India are presented in Table-1.

Table 1: MGNREGA Job Cards and Workers in Odisha \& India

\begin{tabular}{|l|l|c|c|}
\hline \multicolumn{1}{|c|}{$\begin{array}{c}\text { Serial } \\
\text { Number }\end{array}$} & \multicolumn{1}{|c|}{ Job Cards / Workers } & Odisha & India \\
\hline 1 & Total Number of Job Cards (in million) & 6.66 & 132.60 \\
\hline 2 & Total Number of Workers (in million) & 17.88 & 277.90 \\
\hline 2 (a) & $\begin{array}{l}\text { Percentage of Schedules Caste (SC) workers } \\
\text { as of Total Workers (in percentage) }\end{array}$ & 17.90 & 19.55 \\
\hline 2 (b) & $\begin{array}{l}\text { Percentage of Schedules Tribe (ST) workers } \\
\text { as of Total Workers (in percentage) }\end{array}$ & 27.42 & 15.09 \\
\hline 3 & $\begin{array}{l}\text { Total Number of Active Job Cards (in } \\
\text { million) }\end{array}$ & $\begin{array}{l}\text { Total Number of Active Workers (in } \\
\text { million) }\end{array}$ & 3.74 \\
\hline 4 & $\begin{array}{l}\text { Percentage of Schedules Caste (SC) workers } \\
\text { as of Total Active Workers (in percentage) }\end{array}$ & 16.36 & 20.60 \\
\hline 4 (a) & $\begin{array}{l}\text { Percentage of Schedules Tribe (ST) workers } \\
\text { as of Total Active Workers (in percentage) }\end{array}$ & 36.57 & 16.91 \\
\hline
\end{tabular}

Source: MGNREGA website (www.nrega.nic.in) accessed on $1^{\text {st }}$ April 2016.

Total number of job cards in India is 132.60 million and is 6.66 million in Odisha. Out of it total number of active job cards in India is 57.3 million and in Odisha it is 2.37 million. The total number of workers in India and Odisha are respectively 277.9 and 17.88 million. From this the total number of active workers in India and Odisha are respectively 88.0 and 3.74 million. It is interesting to find that percentage of SC workers in the total workers in India and Odisha are respectively $19.55 \%$ and $17.90 \%$. Similarly, the active SC workers in India and Odisha are $20.60 \%$ and $16.36 \%$ respectively. ST beneficiaries in the total beneficiaries in India and Odisha are respectively $15.09 \%$ and $27.42 \%$. Out of this, active workers are respectively $16.91 \%$ and $36.57 \%$ respectively in India and Odisha. Large portion of total population in Odisha belongs to ST category as 
compared to SC category. Active job cards and workers are markedly less than the total job cards and total workers. This reminds us about the 'ghost cards'. In many instances, it was found that even if the beneficiaries do not exist, the job cards do exist.

Table 2: Progress, Works and Financial Progress of MGNREGA in Odisha

\begin{tabular}{|c|c|c|c|c|}
\hline & $\begin{array}{l}2012- \\
13\end{array}$ & $\begin{array}{c}2013- \\
14\end{array}$ & $\begin{array}{l}2014- \\
15\end{array}$ & $\begin{array}{l}2015- \\
16\end{array}$ \\
\hline & \multicolumn{4}{|c|}{ Progress } \\
\hline Approved Labour Budget (₹ millions) & 61.20 & 59.50 & 63.31 & 76.01 \\
\hline Person days Generated so far (millions) & 54.60 & 71.18 & 53.54 & 88.04 \\
\hline $\begin{array}{l}\text { Person days as percentage of Total Labour } \\
\text { Budget (percentage) }\end{array}$ & 89.22 & 119.63 & 84.56 & 115.83 \\
\hline $\begin{array}{l}\text { Percentage of Scheduled Caste (SC) person } \\
\text { days as of Total person days (percentage) }\end{array}$ & 17.60 & 16.35 & 15.82 & 15.89 \\
\hline \multirow[t]{2}{*}{$\begin{array}{l}\text { Percentage of Scheduled Tribe (ST) person } \\
\text { days as of Total person days (percentage) }\end{array}$} & 37.69 & 40.82 & 41.56 & 41.81 \\
\hline & \multicolumn{4}{|c|}{ Works } \\
\hline $\begin{array}{l}\text { Number of Gram Panchayats with no } \\
\text { expenditure }\end{array}$ & 71 & 81 & 142 & 65 \\
\hline $\begin{array}{l}\text { Total Number of Works Taken up (New \& } \\
\text { Spill Over) (millions) }\end{array}$ & 0.24 & 0.28 & 0.32 & 0.54 \\
\hline Number of Ongoing Works (millions) & 0.176 & 0.208 & 0.268 & 0.423 \\
\hline \multirow[t]{2}{*}{ Number of Completed Works (thousands) } & 62.83 & 69.08 & 49.69 & 116.35 \\
\hline & \multicolumn{4}{|c|}{ Financial Progress } \\
\hline Wages (₹ billions) & 6.67 & 9.26 & 7.14 & 15.77 \\
\hline Material and skilled Wages (₹ billions) & 4.43 & 3.02 & 3.00 & 4.07 \\
\hline Total Administrative Expenditure (₹ billions) & 0.68 & 0.58 & 0.55 & 0.64 \\
\hline Total Expenditure (₹ billions) & 11.77 & 12.87 & 10.70 & 20.49 \\
\hline Average Wage rate per day per person $(₹)$ & 124.45 & 141.27 & 161.46 & 187.65 \\
\hline Average Cost Per Day Per Person (₹) & 216.22 & 192.43 & 219.18 & 237.72 \\
\hline
\end{tabular}

Source: MGNREGA website (www.nrega.nic.in) accessed on $1^{\text {st }}$ April 2016.

Progress of MGNREGA, number of public works taken up and financial progress of MGNREGA in Odisha during 2012-13 to 2015-16 are presented in Table-2. Approved labour budget was ₹61.20 million in the financial year 2012-13. In the year 2013-14 it fell to ₹59.50 million afterwards it increased continuously to ₹76.01 million in 2015-16. Person days generated as percentage of total labour budget is highest in the year 201314 , i.e. $119.63 \%$. Percentage of scheduled caste (SC) person days as of total person days constantly declined over the year from 2012-13 to 2015-16. On the other hand, the 
percentage of Scheduled Tribe person days as of total person days gradually increased over the period from 2012-13 to 2015-16. It is remarkable to find that more than $40 \%$ of the beneficiaries are scheduled tribes. In view of the inclusive growth approach this is a good sign for the economy as more and more of the Scheduled Tribe people get public works over the period 2012-13 to 2015-16.

Very often the allotted budget to gram panchayats under the MGNREGA are not spent and the money is returned back. In 2012-13, 71 gram panchayats were unable to spend any amount from out of the MGNREGA budget. This gradually increased to 142 in the year 2014-15. In the year 2015-16 this decreased to 65 gram panchayats. Total number of works taken up (both new and spill over) was 0.24 million in the year 2012-13. Gradually this has increased and it is 0.54 million in the year 2015-16. Number of ongoing works is 0.176 million. This has also increased over the years and the figure is 0.423 million during the year 2015-16. Number of completed work is highest in the year 2015-16, that is 116.35 thousand.

Wages given to the beneficiaries during 2012-13 was ₹6.67 billion. It has increased to $₹ 15.77$ billion in the year 2015-16. This indicates that the participation rates of the people are increasing over the years. Skilled wages and material cost was highest in the year 2012-13 i.e. ₹4.43 billion. It has decreased in the years 2013-14 and 2014-15. However, the situation has improved slightly in the year 2015-16, when it has increased to ₹4.70 billion. Total expenditure incurred was ₹11.77 billion in the year 2012-13. This has declined to ₹10.70 billion in the year 2014-15 but again has risen to ₹20.49 billion in the year 2015-16. Average wage rate per day per person was ₹124.45 in the year 2012-13. It has gradually increased to ₹187.65 in the year 2015-16. Average cost per day per person has also increased. It has risen from ₹216.22 in 2012-13 to ₹237.22 in the year 2015-16. It has been observed that the average wage rates over the years are increasing which is helpful for the beneficiaries.

\section{Data Source and Methodology}

Odisha is situated on the east coast of India along the Bay of Bengal. Odisha stands for its ancient glory and modern endeavour. Endowed with nature's bounty, a $482 \mathrm{~km}$ stretch of coastline with virgin beaches, serpentine rivers, mighty waterfalls, forest-clad blue hills of Eastern Ghats with rich wild life, Odisha is dotted with exquisite temples, historic monuments. Odisha State has a population of 41,947,358 as per 2011 census and covers an area of 155,707 square kilometres. Out of it numbers of male are $21,201,678$ and numbers of female are 20,745,680. In the present study beneficiaries of the selected villages are located from the MGNREGA website. Primary data from the beneficiaries are collected using schedule. The objective behind this is to find out the view of the beneficiaries regarding working of MGNREGA program.

\subsection{Selection Criteria \& District Profile}

Ten districts of Western Odisha lag behind their counterparts of coastal districts in core sectors. ${ }^{5}$ Looking at the degree of development/ backwardness of 10 Western Odisha

\footnotetext{
${ }^{5}$ Eight core sectors include: crude oil, petroleum refinery products, coals, electricity, cement and finished steel. The Western Odisha Development Council (WODC) Act, 2000 empowers the
} 
districts, it can be said that out of 87 blocks only 5 blocks are developed, 25 are developing, another 25 are backward and 32 blocks are very backward.

Table 3: Demographic profile of the districts under study (as per 2011 census)

\begin{tabular}{|l|c|c|c|c|c|c|}
\hline \multirow{2}{*}{$\begin{array}{c}\text { State/ } \\
\text { District }\end{array}$} & \multirow{2}{*}{$\begin{array}{c}\text { Total } \\
\text { Population } \\
\text { (Millions) }\end{array}$} & \multirow{2}{*}{$\begin{array}{c}\text { Sex } \\
\text { Ratio }\end{array}$} & \multirow{2}{*}{$\begin{array}{c}\text { Population } \\
\text { Density }\end{array}$} & \multicolumn{3}{c|}{ Literacy Rate } \\
\cline { 5 - 7 } & & & Person & Male & Female \\
\hline Odisha & 41.95 & 978 & 269 & 73.45 & 82.40 & 64.36 \\
\hline Bargarh & 1.48 & 976 & 253 & 75.16 & 84.28 & 65.84 \\
\hline Sambalpur & 1.04 & 973 & 158 & 76.91 & 85.17 & 68.47 \\
\hline Sonepur & 0.65 & 959 & 279 & 74.42 & 84.78 & 63.63 \\
\hline
\end{tabular}

Source: Author's own calculation.

\subsection{Sample Size and Sampling Procedure}

The selected block and selected sample villages are presented in table 4 . The three districts out of these ten districts are selected conveniently, i.e. using convenience sampling. These districts are Bargarh, Sambalpur and Sonepur. Out of these districts one block is selected from each district using simple random sampling. Then out of these three blocks one village from each block is selected using simple random sampling except Sambalpur. In Sambalpur from the selected block Dhankauda, two villages are selected using simple random sampling.

Table 4: List of Sample Village

\begin{tabular}{|c|c|c|c|c|}
\hline $\begin{array}{c}\text { Sl. } \\
\text { No. }\end{array}$ & District & Block & Gram Panchayat & Village \\
\hline 1 & Sambalpur & Dhankauda & Katapali & Katapali \\
\hline 2 & Sambalpur & Dhankauda & Kalamati & BudhiKhamar \\
\hline 3 & Sonepur & Birmaharajpur & Bagbar & Lumurjena \\
\hline 4 & Bargarh & Bhatli & Mulbar & Runipali \\
\hline
\end{tabular}

Source: Author's own calculation.

The comparative implementation experiences of MGNREGA in the districts are summarised in terms of the indicators. Assessment of these indicators is based on both qualitative observations and quantitative data generated by the study. Beneficiary

Council for the socio-economic, educational, cultural advancement and development of the people residing within the WODC area. (http://www.wodcodisha.nic.in/frmaboutus.aspx). 
schedule was constructed for MGNREGA Scheme basing on thematic approach ${ }^{6}$. These include broad categories of socio economic details, awareness, participation, process, monitoring and supervision, payment details, transparency, work site facilities and effectiveness. A robust analytics framework evolved from the objectives with right approach to survey designing, administering, analysis and identifying action items for continual improvements. The size of the sample selected in the four villages Katapali, Budhi Khamar, Lumurjena and Runupali are respectively 46, 30, 62 and 60.

\section{Findings and analysis}

The present work is an attempt to assess the working of MGNREGA in Western Odisha. The households were interviewed by taking their names from the MGNREGA website (www.nrega.nic.in) i.e. those households worked under the MGNREGA scheme in their respective villages.

\subsection{Issues relating to card holding}

In India, ration cards are used primarily for purchasing subsidized food stuffs (wheat and rice) and fuel (LPG and kerosene). These are important subsistence tools for the poor; provide proof of identity and a connection with government databases. Indian public distribution system (PDS) is based on the ration card, which it uses to establish identity, eligibility and entitlement. It is evolved as a system of management of scarcity and for distribution of food grains at affordable prices. BPL, APL and Antyodaya like many systems are part of ration card. Padi card is a type of ration card which is used as a public distribution system.

In Katapali village $69.56 \%$ of the households do not possess any type of card (Table 5). Only $19.56 \%$ are having BPL and $8.7 \%$ are having Antyodaya card. Similarly, in Budhi Khamar village 53.33\%, whose names are present in the MGNREGA scheme list do not have ration card and $30 \%$ of this village have BPL card. About $60 \%$ of the sample households of Lumurjena village are having BPL card and $25.81 \%$ are having no card. In Runipali village of Bargarh district 53.33 percent are having BPL card and 23.33 percent are having padi card.

It is evident that more than half of the beneficiaries in Katapali and Budhi Khamar villages do not possess any types of cards. The objective of possessing these types of cards indicate that the households get essential items like rice, wheat, sugar, kerosene etc. at a subsidized rate. Not possessing these cards debars household to get these items at subsidized rate, which is an additional burden for the households.

\footnotetext{
${ }^{6}$ Thematic analysis is a method for identifying, analysing and reporting patterns within data. It emphasizes pinpointing, examining recording patterns within data. Themes are recording patterns across data sets and are associated to specific research question. The themes become the categories for analysis. Thematic analysis is performed through the process of coding to create established meaningful patterns. Thematic analysis is most useful in capturing the complexities of meaning within a textual data set.
} 
Table 5: Types of Card Holders in percentage

\begin{tabular}{|c|c|c|c|c|c|}
\hline Sl. No. & Particular & Katapali & Budhi Khamar & Lumurjena* & Runipali \\
\hline 1 & BPL & 19.56 & 30.00 & 59.68 & 53.33 \\
\hline 2 & APL & 2.17 & 6.67 & 3.22 & 16.67 \\
\hline 3 & Antyodaya & 8.7 & 0 & 17.74 & 0 \\
\hline 4 & Control card & 0 & 10.00 & 0 & 0 \\
\hline 5 & Padi card & 0 & 0 & 0 & 23.33 \\
\hline 6 & No card & 69.56 & 53.33 & 25.81 & 6.67 \\
\hline
\end{tabular}

Source: Author's own calculation.

It can be seen from Table 6 that all sample households are aware of important aspects of MGNREGA in Budhi Khamar and Runipali villages. Important aspects refer to awareness about the provisions of the Act in exercising the demand to work and other entitlements under MGNREGA. These includes: i) awareness about unemployment allowance; ii) awareness about work on demand; and iii) awareness about grievance redressal mechanism. Generally, awareness among potential beneficiaries about certain provisions of MGNREGA scheme is very low, Ministry of Rural Development (2012). Though the beneficiaries might have heard about the MGNREGA scheme, they are not aware of their entitlements or that they need to ask for work. However, the situation is just the reverse in Budhi Khamar and Runipali, i.e. all are aware of the safety nets program under MGNREGA. This is because government officials have explained MGNREGA in these villages. However, this is not explained by the officials in Katapali and Lumurjena villages. To take the full benefit of MGNREGA scheme it is always advisable to explain the same to beneficiary household by government officials.

Table 6: Awareness of the Households about MGNREGA amongst Potential Wage Earners in percentage

\begin{tabular}{|c|l|c|c|c|c|}
\hline $\begin{array}{c}\text { Sl. } \\
\text { No }\end{array}$ & \multicolumn{1}{|c|}{ Particular } & Katapali & $\begin{array}{c}\text { Budhi } \\
\text { Khamar }\end{array}$ & Lumurjena & Runipali \\
\hline 1 & $\begin{array}{l}\text { Households aware of important } \\
\text { aspects of MGNREGA }\end{array}$ & 0 & 100 & 6.45 & 100 \\
\hline
\end{tabular}

Source: Author's own calculation.

There is a significant difference among the four villages with respect to job card issued as presented in Table - 7. The problem is more acute in Katapali village with $39.13 \%$ of the households enrolled officially under MGNREGA not having job cards. Similarly, in Lumurjena village $14.51 \%$ of households do not have job cards. But in the rest of the two villages, all who are working under MGNREGA scheme do have job cards. However, except $3.22 \%$ of households in Lumurjena village, households of the other villages have not applied for job cards. The level of awareness about MGNREGA among these potential wage earners is also low in Katapali and Lumurjena Village. 
Table 7: Job Card Status of the Sample Households in percentage

\begin{tabular}{|c|c|c|c|c|c|}
\hline $\begin{array}{c}\text { Sl. } \\
\text { No. }\end{array}$ & Particular & Katapali & $\begin{array}{c}\text { Budhi } \\
\text { Khamar }\end{array}$ & Lumurjena & Runipali \\
\hline 1 & $\begin{array}{c}\text { Households who have } \\
\text { applied for job cards }\end{array}$ & 0 & 0 & 3.22 & 0 \\
\hline 2 & $\begin{array}{c}\text { Households who had } \\
\text { obtained job cards }\end{array}$ & 60.87 & 100 & 82.26 & $100 *$ \\
\hline 3 & $\begin{array}{c}\text { Households who had no job } \\
\text { cards }\end{array}$ & 39.13 & 0 & 14.51 & 0 \\
\hline
\end{tabular}

Source: Author's own calculation.

Note: * Two households have double job cards.

As government officials have explained the usefulness of the MGNREGA scheme, all sample households in Budhi Khamar and Runipali villages have job cards. If the importance of MGNREGA could have been explained, most of the households could have job cards, particularly in Katapali and Runipali Villages. Also, most of the beneficiaries of MGNREGA schemes are illiterates in all sample villages. Therefore, the households are unaware of the benefits associated with this scheme.

\subsection{Working Conditions}

Road construction is the main activity in which the households are engaged. In Katapali and Lumurjena the households are also engaged in digging of ponds. Some people also work in dam in Lumurjena village. The average wage rate they should get is also varying. In the villages Budhi Khamar and Runipali, the workers are getting Rs. 125/per day as per the norms while in Katapali and Lumurjena they are getting Rs. 102.92/and Rs. 102/- respectively (Table 8). Even if the per day wage rate is Rs 125/-, beneficiaries in Katapali and Lumurjena are getting less as they are unaware of the wage rate. Also, the infrastructure created using MGNREGA scheme is of questionable quality. The workers are basically unskilled or semi-skilled. It is also found that old persons possessing job card do lethargic work.

In the sample villages, the types of infrastructure created are only road construction, digging of pond or works in check dam. As mentioned earlier, Mihir Shah Committee recommended 30 types of infrastructure that can be created under MGNREGA scheme. Clearly this is not followed in the sample villages. It is also interesting to find that the same work is being repeated in subsequent years. As pointed out by the beneficiaries the same road is constructed and digging of pond is done in two consecutive years. Basic amenities like first aid box and sheds for keeping babies at worksite are not found at any of the sample villages. Even drinking water is not provided at the worksite in Katapali and Lumurjena Villages. 
Table 8: Working Conditions of Households under MGNREGA Scheme

\begin{tabular}{|c|c|c|c|c|c|}
\hline $\begin{array}{c}\text { Sl. } \\
\text { No. }\end{array}$ & Particular & Katapali & BudhiKhamar & Lumurjena & Runipali \\
\hline 1 & $\begin{array}{c}\text { Average } \\
\text { wage rate }\end{array}$ & 102.92 & 125 & 102 & 125 \\
\hline 2 & $\begin{array}{c}\text { Type of } \\
\text { activity } \\
\text { construction } \\
\text { and digging of } \\
\text { pond }\end{array}$ & $\begin{array}{c}\text { Road } \\
\text { construction }\end{array}$ & $\begin{array}{c}\text { Road } \\
\text { construction and } \\
\text { digging of pond } \\
\text { and works in } \\
\text { dam }\end{array}$ & $\begin{array}{c}\text { Road } \\
\text { construction }\end{array}$ \\
\hline 3 & $\begin{array}{c}\text { Facilities } \\
\text { available at } \\
\text { the work } \\
\text { site }\end{array}$ & No facilities & $\begin{array}{c}\text { Drinking } \\
\text { water }\end{array}$ & No facilities & $\begin{array}{c}\text { Drinking } \\
\text { water }\end{array}$ \\
\hline
\end{tabular}

Source: Author's own calculation.

Again, in Budhi Khamar and Runipali villages, while the households enrolled under MGNREGA are actually getting a job at least for some days, but in Katapali and Lumurjena they are not getting a job (Table 9). The situation is the worst in Katapali where only 26.08 percent of the households get a job. So, the documentation carried out by government officials is vague.

Table 9: Perceptions of Households about MGNREGA Scheme in percentage

\begin{tabular}{|c|c|c|c|c|c|}
\hline $\begin{array}{c}\text { Sl. } \\
\text { No. }\end{array}$ & Particular & Katapali & $\begin{array}{c}\text { Budhi } \\
\text { Khamar }\end{array}$ & Lumurjena & Runipali \\
\hline 1 & $\begin{array}{c}\text { Households who said } \\
\text { they got work }\end{array}$ & 26.08 & 100 & 83.87 & 100 \\
\hline 2 & $\begin{array}{c}\text { Average number of } \\
\text { days of work obtained }\end{array}$ & 75.42 & 68.53 & 53.69 & 26.15 \\
\hline 3 & $\begin{array}{c}\text { Households who got } \\
\text { full payment }\end{array}$ & 100 & 100 & 100 & 100 \\
\hline 4 & $\begin{array}{c}\text { Satisfied with the } \\
\text { functioning of } \\
\text { MGNREGA }\end{array}$ & 2.17 & 100 & 14.52 & 100 \\
\hline 5 & Wage advance & 0 & 10 & 0 & 0 \\
\hline
\end{tabular}

Source: Author's own calculation.

Basically the beneficiaries working under MGNREGA for wage employment are illiterate. Taking this advantage, a middleman in Runipali village collects all the job cards from the households. He takes the beneficiaries to the bank / post office to collect their wages. The households claim that the middleman helps them in getting their wage 
from the bank / post-office. However, the work of the middleman is suspicious. Surprisingly, some of the job cards are in the name of persons who are already dead or they have migrated to some places. Authorities should take necessary steps to find out these types of cases and cancel their job cards. In Katapali and Lumurjena the households are not satisfied in the way the MGNREGA is functioning. Those who got the work, the average number of days of work they got were far less than 100 days. It is only 26.15 days in Runipali village. All these things lead to households losing faith in MGNREGA. However, the good thing is that those who have worked have received their payments and only 10 percent in Budhi Khamar village have taken some wage advance.

In almost all the villages a written format of the application is kept. Persons interested to work under MGNREGA scheme have to collect these formats of application, either put signature or thumb impression and deposit the same in the panchayat office. However, the beneficiaries are simply innocent about the benefits associated with these applications and how they are helpful for them as shown in Table-10. They do not know why a written application is required. Government officials should take necessary steps to explain these to the associated benefits of the scheme. One immediate solution may be to show these to the beneficiaries in documentary / short films.

Table 10: Awareness regarding Writing of Application for Employment in percentage

\begin{tabular}{|c|c|c|c|c|c|}
\hline $\begin{array}{c}\text { Sl. } \\
\text { No. }\end{array}$ & Particular & Katapali & $\begin{array}{c}\text { Budhi } \\
\text { Khamar }\end{array}$ & Lumurjena & Runipali \\
\hline 1 & $\begin{array}{c}\text { Households with } \\
\text { written work } \\
\text { application }\end{array}$ & 0 & 76.67 & 0 & 18.33 \\
\hline 2 & $\begin{array}{c}\text { Households not } \\
\text { aware that a } \\
\text { written application } \\
\text { needs to be given }\end{array}$ & 84.78 & 0 & 0 & 0 \\
\hline 3 & Cannot write & 15.22 & 23.33 & 0 & 81.67 \\
\hline
\end{tabular}

Source: Author's own calculation.

The issues of timely payment and regular and adequate amount of work are critical elements for the success of MGNREGA. In these areas, though they are getting the payments in time, the provision of adequate and regular amount of work is the most important problem. In Runipali village those who are interested to work are given employment for a few days and the remaining part of the work is completed by using machines. Only 2.17 percent in Katapali and 14.52 percent in Lumurjena villages are satisfied with the functioning of MGNREGA.

People who applied for work are 76.67 percent in Budhi Khamar village and 18.33 percent in Runipali village. In the rest of the two villages they are not aware that a written application needs to be given for work under MGNREGA. In Runipali village 81.67 percent of the beneficiaries do not know how to write the application for work. 
The study clearly indicates that there lies a demand for work via MGNREGA in all these four villages. In three villages except Katapali, people have migrated recently for work. In the future, most of the beneficiaries are interested to work in MGNREGA if it is properly implemented.

\section{Table 11: Migration and Perception of Households regarding Future Employment}

\begin{tabular}{|c|c|c|c|c|c|}
\hline $\begin{array}{c}\text { Sl. } \\
\text { No. }\end{array}$ & Particular & Katapali & $\begin{array}{c}\text { Budhi } \\
\text { Khamar }\end{array}$ & Lumurjena & Runipali \\
\hline 1 & $\begin{array}{c}\text { Whether anyone has } \\
\text { migrated in the near } \\
\text { past for work }\end{array}$ & 0 & 26.67 & 3.22 & 25.00 \\
\hline 2 & $\begin{array}{c}\text { In future interested to } \\
\text { work in MGNREGA }\end{array}$ & 91.31 & 100 & 100 & 100 \\
\hline 3 & $\begin{array}{c}\text { Think to get work in } \\
\text { time }\end{array}$ & $\begin{array}{c}\text { In future if } \\
\text { MGNREGA is } \\
\text { properly } \\
\text { implemented } \\
\text { interested to work }\end{array}$ & 100 & 100 & 100 \\
\hline
\end{tabular}

Source: Author's own calculation.

Perception of household regarding future employment and migration are presented in Table: 11 . The type of migration that is prevalent in the study area is distress migration. Families migrate from these areas to Andhra Pradesh, Karnataka and Tamil Nadu etc. in search for a job. The study indicates that in the village Katapali nobody has migrated in the near past. Similarly, 3.22\% people of Lumurjena village migrated in search for a job. The situation is worse in Budhi Khamar and Runipali where respectively $26.67 \%$ and $25.00 \%$ of the family members of the respondents have migrated. The perception of the households regarding future employment in MGNREGA is very good. Almost in all the sample villages all the MGNREGA beneficiaries are interested to work in the scheme. Their perception also is that they will get the work in time in future. If implemented properly, it is interesting to find that all the beneficiaries in the sample villages are interested to work in the scheme.

\section{Conclusions}

MGNREGA is a social safety net programme for millions of poor people. Despite its loopholes, it has achieved significant results. In order to make it more effective the following remarks are drawn with regard to the present study.

MGNREGA Scheme catered to the generic village building initiatives. The program did not differentiate educated/skilled workers from unskilled/illiterate. The program remained true to its 'right to work' entailments and did not counsel households that approached for works with better living standards. Lack of awareness is identified in the present study as a severe bottleneck that reflected in poor understanding of minimum 
wage, unemployment allowance, accident compensation, employment opportunities and overall MGNREGA process. The program did not have any upper ceiling limit on age. Old people undergo laborious work and instill lethargic work culture among the beneficiaries.

Safety net program like MGNREGA scheme was initiated with the strategy of transferring some purchasing power in the hands of poor or marginalized people. The underlying objectives are to effectively tackle poverty, enhance growth's effectiveness in reducing poverty and stimulate economic growth. In return some infrastructure can be created for the village with the work effort these people provide. However, it is found that these infrastructures which are supposed to be created are of questionable quality. Also, the same work is undertaken repeatedly at the village level in successive years.

There are a number of constraints in the success of the scheme. The beneficiaries are mostly illiterate. Taking this advantage middleman take the benefit in the sense that they pay less to the beneficiaries after collecting their dues from either bank or post office. In a low income state like Odisha money sanctioned under MGNREGA scheme are unutilized and are returned to the Ministry. Therefore, proper implementation of the scheme is a major challenge for the officials at state, district and panchayat levels.

With the recommendation of the Mihir Shah Committee, i.e. MGNREGA 2.0, 30 agriculture and allied works were streamlined under public works. But, none of these were implemented in the sample villages as evident from our present study. The villages preferred constructing roads or digging ponds. The present research suggests a few changes desired in the act for a better performance. They are: identifying village requirements based on secondary research; monitoring the effectiveness of programs, restricting the use of machines and creating more opportunities of employment for rural poor. Multiplier effects of cash transfers by public works can improve livelihood of the beneficiaries, if loopholes and gap in implementation of the scheme are reduced. They can improve human development of the community.

Acknowledgement: I would like to thank Dr. (Mrs.) Lopamudra Mishra for her helpful comments and advice. I would like to thank two anonymous referees for their useful suggestions and comments.

Disclosure statement: No potential conflict of interest was reported by the author.

\section{References}

AFRIDI, F., and V. IVERSEN. (2013). Social Audits and MGNREGA Delivery: Lessons from Andhra Pradesh, India Policy Forum, National Council of Applied Economic Research, New Delhi, pp. 297-331.

AFRIDI, F. (2016). 10 years of MGNREGA and the way forward, e-symposium, Ideas for India, New Delhi. http://www.ideasforindia.in/article.aspx?article id=1594. 
BARRIENTOS, A. (2012). Social Transfers and Growth: What Do We Know? What Do We Need to Find Out? World Development, 40 (1), pp. 11-20. DOI: 10.1016/j.worlddev.2011.05.012

BARRIENTOS, A. and J. SCOTT. (2008). Social Transfers and Growth A Review. BWPI Working Paper 52, Brooks World Poverty Institute, University of Manchester, Manchester.

BASU, A. K. (2013). Impact of Rural Employment Guarantee Schemes on Seasonal Labor Markets: Optimum Compensation and Workers' Welfare, Journal of Economic Inequality, 11(1), pp. 1-34. DOI: 10.1007/s10888-011-9179-y

BONNER, K. et al, (2012). MGNREGA Implementation: A Cross-State Comparison, Woodrow Wilson School of Public and International Affairs, Princeton University, pp. $1-50$.

CHAKRABORTY, P. (2007). Implementation of Employment Guarantee: A Preliminary Appraisal, Economic \& Political Weekly, Vol. 42, No. 7, February, pp. 548551.

CHATTOPADHYAY, S. (2015). The Political Economy of Welfare Schemes, Livemint, Opinion, October 27, also published in the World Bank blog Public Sphere, on November 17: http://blogs.worldbank.org/publicsphere/political-economy-welfareschemes.

DEL NINNO, C., K. SUBBARAO, and A. MILAZZO. (2009). How to Make Public Works Work: A Review of the Experiences. World Bank, Social Protection Discussion Paper No. 0905, pp. 1 - 78.

DEVELOPMENT COMMITTEE, (2012). Safety Nets Work: During Crisis and Prosperity. Joint Ministerial Committee of the Boards of Governors of the World Bank and the International Monetary Fund on the Transfer of Real Resources to Developing Countries, DC2012-0003, April 11.

DEVEREUX, S. et al, (2015). Evaluating the Targeting Effectiveness of Social Transfers: A Literature Review, IDS Working Paper, Vol. 2015, No. 460, Center for Social Protection, Working Paper No. 012, July.

DUTTA, P., R. MURGAI, M. RAVALLION, and D. DE WALLE. (2012). Does India's Employment Guarantee Scheme Guarantee Employment? World Bank, Policy Research Working Paper No.: 6003, pp. 1-32.

DUTTA, P., R. MURGAI, M. RAVALLION, and D. DE WALLE. (2014). Right-toWork? Assessing India's Employment Guarantee Scheme in Bihar, World Bank, Equity and Development Series, Washington DC, pp. 1-255.

GOVERNMENT OF INDIA, (2005). The National Rural Employment Guarantee Act 2005: Operational Guidelines. Ministry of Rural Development, New Delhi.

GROSH, M., C. DEL NINNO, E. TESLIUC, and A. OUERGHI. (2008). For Protection and Promotion: The Design and Implementation of Effective Safety Nets. 'Chapter 5: Benefit Levels and Delivery Mechanisms' and 'Chapter 7: Understanding Common Interventions'. World Bank. 
HAGEN-ZANKER, J., A. MCCORD, and R. HOLMES. (2011). Systematic Review of the Impact of Employment Guarantee Schemes and Cash Transfers on the Poor. Overseas Development Institute, London, June.

IEG. (2011). Social Safety Nets: An Evaluation of World Bank Support, 2000-2010. Washington, DC: Independent Evaluation Group, World Bank.

IMBERT, C., and J. PAPP. (2012). Equilibrium Distributional Impacts of Government Employment programs: Evidence from India's Employment Guarantee, Working Paper No.: 14, Paris School of Economics, Paris, pp. 1-75.

JOHNSON, D. et al, (2009). NREGA in Andhra Pradesh: Seven Lessons from Data, CMF Focus Note, IFMR: Centre for Microfinance, No. 4, November, pp. 1-14.

JORGENSEN, S., and R. SERRANO-BERTHET. (2009). Comprehensive Social Policy for Inclusive and Sustainable Globalization, in Building Equality and Opportunity through Social Guarantees: New Approaches to Public Policy and the Realization of Rights, (Eds.) Estanislao Gacitúa-Marió, Andrew Norton and Sophia V. Georgieva, World Bank, Washington DC, pp. 45-68.

KHERA, R., and N. NAYAK. (2009). Women Workers and Perceptions of the National Rural Employment Guarantee Act, Economic \& Political Weekly, Vol. XLIV, No. 43, October, pp. 49-57.

KIDD, S. (2015). The Political Economy of "Targeting" of Social Security Schemes, Pathways Perspectives: On Social Policy in International Development, Issue No. 19, October.

KULKARNI, A. (2014). Is the Proposed Restructuring of MGNREGA Desirable? Livemint, Opinion, October 20.

LAL, R., S. MILLER, M. LIEUW-KIE-SONG, and D. KOSTZER. (2010). Public Works and Employment Programmes: Towards a Long-term Development Approach. Working Paper No.: 66, International Policy Centre for Inclusive Growth, Poverty Group, UNDP, Brazil.

LIN, J. Y., and D. ROSENBLATT. (2012). Shifting patterns of economic growth and rethinking development, Journal of Economic Policy Reform, 15(3), pp. 171-194. DOI: $\underline{10.1080 / 17487870.2012 .700565}$

MCCORD, A. (2007). The social protection function of short-term public works programs in the context of chronic poverty. in A. Barrientos, \& D. Hulme (Eds.), Social Protection for the Poor and Poorest: Concepts, Policies and Politics, London: Palgrave.

MINISTRY OF RURAL DEVELOPMENT, (2013). Mahatma Gandhi National Rural Employment Guarantee Act, 2005 (Mahatma Gandhi NREGA): Operational Guidelines. $4^{\text {th }}$ Edition, Government of India New Delhi.

MINISTRY OF RURAL DEVELOPMENT, (2012). MGNREGA Sameeksha: An Anthology of Research Studies on the Mahatma Gandhi National Rural Employment Guarantee Act, 2005, 2006-2012. Government of India, Edited and compiled by Mihir Shah, Nilakshi Mann and Varad Pande, New Delhi: Orient Black Swan. 
NARAYANAN, S. (2016). MGNREGA and its Assets, Ideas for India, New Delhi, http://www.ideasforindia.in/article.aspx?article_id=1596

PLANNING COMMISSION, (2012). Report of the 12th Plan (2012-2017): Steering Committee on Rural Livelihoods and Rural Governance, Rural Development Division, Government of India, January.

PRABHU, K.S. (2009). Conditional Cash Transfer Schemes for Alleviating Human Poverty: Relevance for India. Discussion Paper: 1, April, pp. 1-28.

RAABE, K., R. BIRNER, M. SEKHER, K.G. GAYATHRIDEVI, A. SHILPI, and E. SCHIFFER. (2010). How to Overcome the Governance Challenges of Implementing NREGA: Insights from Bihar Using Process-Influence Mapping, Development Strategy and Governance Division, IFPRI Discussion Paper 00963, April.

REDDY, D.N. et al, (2010). National Rural Employment Guarantee as Social Protection, IDS Bulletin, Vol. 41 No. 4, July, pp. 63-74. DOI: $\underline{10.1111 / j .1759-}$ 5436.2010.00153.x

SEN, K. (2016). MNREGA, 10 years on: Glass half-full or half-empty? Ideas for India, New Delhi, http://www.ideasforindia.in/article.aspx?article_id=1601

SUBBARAO, K., C. DEL NINNO, C. ANDREWS, and C. RODRIGUEZ-ALAS. (2013). Public Works as a Safety Net: Design, Evidence and Implementation, Washington D.C.: World Bank, pp. 1-403.

UNITED NATIONS DEVELOPMENT PROGRAM (UNDP), (2016). UNDP Support to the Implementation of the 2030 Agenda for Sustainable Development, UNDP Policy and Programme Brief, New York, January.

UNITED NATIONS DEVELOPMENT PROGRAM (UNDP), (2015). Human Development Report: Work for Human Development, New York, pp. 1-272.

UNITED NATIONS DEVELOPMENT PROGRAM (UNDP), (2009). Employment guarantee quickening India's march towards MDGs. Report on an International Seminar on Rural Poverty: Key initiatives in achieving Millennium Development Goals and the role of NREGA, National Agricultural Science Centre, New Delhi, January 21-22.

WORLD BANK, (2015). The State of Social Safety Nets 2015, Washington D.C., pp. 1164.

ZEPEDA, E., S. MCDONALD, M. PANDA, and G. KUMAR. (2013). Employing India: Guaranteeing Jobs for Rural Poor, Carnegie Endowment and UNDP, Washington D.C., pp. 1-74

ZEPEDA, E., and D. ALARCON. (2012). Which Way to Reduce Poverty: Cash Transfers or Employment Guarantee Scheme? In Ashok K. Pankaj (Ed.) Right to Work and Rural India: Working of the Mahatma Gandhi National Rural Employment Guarantee Scheme (MGNREGS), Sage Publication India Pvt. Ltd., New Delhi, pp. 8197.

ZIMMERMANN, LAURA. (2013). Why Guarantee Employment? Evidence from a Large Indian Public-Works Program, Ann Arbor: University of Michigan. 
REVIEW OF ECONOMIC PERSPECTIVES

ZIMMERMANN, LAURA. (2014). Public-Works Programs in Developing Countries, IZA World of Labor, 25, pp. 1-10. 